University of Montana

ScholarWorks at University of Montana

$5-2003$

\title{
Phenotypic Plasticity and Interactions Among Plants
}

Ragan M. Callaway

University of Montana - Missoula, Ray.Callaway@mso.umt.edu

Steven C. Pennings

Christina L. Richards

Follow this and additional works at: https://scholarworks.umt.edu/biosci_pubs

Part of the Biology Commons

Let us know how access to this document benefits you.

\section{Recommended Citation}

Callaway, Ragan M.; Pennings, Steven C.; and Richards, Christina L., "Phenotypic Plasticity and Interactions Among Plants" (2003). Biological Sciences Faculty Publications. 307.

https://scholarworks.umt.edu/biosci_pubs/307

This Article is brought to you for free and open access by the Biological Sciences at ScholarWorks at University of Montana. It has been accepted for inclusion in Biological Sciences Faculty Publications by an authorized administrator of ScholarWorks at University of Montana. For more information, please contact

scholarworks@mso.umt.edu. 


\title{
PHENOTYPIC PLASTICITY AND INTERACTIONS AMONG PLANTS
}

\author{
Ragan M. Callaway, ${ }^{1,4}$ Steven C. Pennings, ${ }^{2}$ and Christina L. Richards ${ }^{3}$ \\ 'Division of Biological Sciences, University of Montana, Missoula, Montana 59812 USA \\ ${ }^{2}$ Department of Biology and Biochemistry, University of Houston, Houston, Texas 77204-5001 USA \\ ${ }^{3}$ Department of Botany, University of Georgia, Athens, Georgia 30602 USA
}

\begin{abstract}
We know a great deal about the plastic responses of plant phenotypes to the abiotic and biotic environment, but very little about the consequences of phenotypic plasticity for plant communities. In other words, we know that plant traits can vary widely for a given genotype, but we know little about the importance of trait-mediated interactions (TMI) among plants. Here, we discuss three major factors that affect the expression of phenotypic plasticity: variation in the abiotic environment, variation in the presence or identity of neighbors, and variation in herbivory. We consider how plastic responses to these factors might affect interactions among plants. Plastic responses to the abiotic environment have important consequences for conditionality in competitive effects, to the point of causing shifts from competitive to facilitative interactions. Because plants show a high degree of plasticity in response to neighbors, and even to the specific identify of neighbors, phenotypic plasticity may allow species to adjust to the composition of their communities, promoting coexistence and community diversity. Likewise, plastic responses to consumers may have various and counterintuitive consequences: induction of plant resistance, compensatory growth, and increased resource uptake may affect interactions among plants in ways that cannot be predicted simply by considering biomass lost to consumers. What little we know about TMI among plants suggests that they should not be ignored in plant community theory. Although work to date on the community consequences of phenotypic plasticity has been hampered by experimental constraints, new approaches such as manipulating phenotypes by using signals instead of actual environmental conditions and the use of transgenic plants should allow us to rapidly expand our understanding of the community consequences of plant plasticity.
\end{abstract}

Key words: allelopathy; chemical defense; clonal morphology; competition; facilitation; herbivory; induced resistance; phenotypic plasticity; plant interactions; roots.

\section{INTRODUCTION}

Phenotypic plasticity is the property of a given genotype to produce different physiological or morphological phenotypes in response to different environmental conditions (Bradshaw 1965, 1973, Schlichting 1986, Sultan 1987, Schlicting and Pigliucci 1998, Pigliucci 2001). A given plant genotype can experience different environmental conditions as a result of variation in the abiotic environment, variation in the presence or identity of neighbors, or variation in consumer pressure. Variation in trait expression induced by these or other environmental factors might then affect interactions among plants. Although the evolutionary aspects of phenotypic plasticity in plants have been extensively examined, the ecological ramifications are less well understood.

As a rule, plants are highly plastic (Sultan 1987, 2000). Individuals within a species may vary by orders of magnitude in size, growth rates, allocation to different organs, reproduction, and chemical constituency.

Manuscript received 25 September 2001; revised 16 April 2002; accepted 19 April 2002; final version received 6 June 2002. Corresponding Editor: F. R. Adler. For reprints of this Special Feature, see footnote 1, p. 1081.

${ }^{4}$ E-mail: callaway@selway.umt.edu
Plants display plastic responses to a wide variety of ecological conditions including variation in the abiotic environment, disturbance, herbivory, parasitism, mutualistic relationships, and the presence, absence, or identity of neighbors. Plastic responses may be permanent once induced, relatively fixed for a given growing season, or may be dynamic on a scale of hours, as in the case of light effects on photosynthetic chemistry or herbivore effects on defense chemistry (Baldwin 1999, Pearcy 1999). Although the cues that trigger phenotypic differences are environmental, the ability to respond to cues is genetically based and can evolve under natural selection (Bradshaw 1973, Via 1994). Genetic variation in phenotypic plasticity (known as a significant $G \times E$ interaction) is an indicator of the potential for response to selection and the maintenance of plasticity in a population (Via and Lande 1985, Van Tienderen 1991). Plasticity is favorable if the environment is variable, if environmental cues are reliable such that individuals can express the appropriate phenotype in each environment, and if there are costs to inappropriate, specialized phenotypes. Specialization is favored over plasticity when these conditions are not met, and is also favored by a variety of inherent costs to plasticity (Van Tienderen 1991, Dorn et al. 2000, Re- 
lyea 2002; but see Sultan 1995). Because individual genotypes have the potential for adaptive divergence, plasticity in plants probably broadens ecological ranges and reduces the impact of selection (Mazer and Schick 1991, Sultan 1995).

Although phenotypic plasticity may not always be adaptive, the adaptive benefits of plastic traits as "buffers against spatial or temporal variability in habitat conditions" and "means of optimizing the acquisition and use of resources" (Grime et al. 1986, Robinson and Rorison 1988) have been widely documented and reviewed (Bradshaw 1965, Schlichting 1986, Sultan 1987, 1995, Stearns 1989, Debat and David 2001). In contrast to our understanding of the evolutionary ecology of phenotypic plasticity, which is well established and rapidly advancing, we know little about the consequences of plasticity for ecological interactions in plant communities. For example, phenotypic plasticity may alter the sign and magnitude of interactions among plants, but the role of such trait-mediated interactions (TMI) has been largely overlooked in plant community ecology. Thus, an explicit research focus on TMI could revolutionize some aspects of plant ecology.

Interactions among plants vary along a continuum from strongly competitive to strongly facilitative. The nature of the interaction between two species of plants is not always fixed, but may be conditional depending on environmental conditions. In other words, a species may be competitively superior to a particular neighbor under one set of conditions, but not under another. Similarly, a species may have positive effects on neighbors (facilitation) in some conditions and negative effects (competition) in other conditions (Bertness and Callaway 1994, Callaway 1995). A wide range of environmental circumstances including the particular suites and amounts of available resources, various environmental stresses, the composition of surrounding communities, herbivory, and physical disturbance may shift the balance of competition among species (Wilson and Keddy 1986, Louda et al. 1990, Miller 1994, Levine et al. 1998, Callaway and Pennings 2000). All of these conditions also have important effects on phenotypic plasticity (Sultan and Bazzaz 1993a, b, $c$, Emery et al. 1994, Donohue et al. 2000a, b, 2001, Weinig 2000a, $b, c$, Weinig and Delph 2000). Although many studies have considered the direct consequences of variation in environmental factors on competition, relatively few have considered the impact of effects mediated through phenotypic plasticity. In general, high phenotypic plasticity has been thought to confer superior invasive and competitive abilities (Bloom et al. 1985, Poorter and Lambers 1986, Aerts et al. 1991, Grime et al. 1991, Aerts 1999, Sultan 2000, 2001), but few studies have explicitly tested this hypothesis.

Here we explore three major factors that affect the expression of phenotypic plasticity: variation in the abiotic environment, variation in the presence or identity of neighbors, and variation in herbivory. Under- standing the relationship between phenotypic plasticity and plant interactions has been limited by experimental constraints. First, it is difficult to separate the effects of plasticity from the confounding effects of the treatments used to create plasticity. Second, it is difficult to assess the performance of all phenotypes in all environments because plasticity prevents the expression of inappropriate phenotypes in each environment (Schmitt 1993, Schmitt et al. 1999). Because of these experimental constraints, we know far more about the plastic responses of plants to the environment than we do about the consequences of plasticity for interspecific interactions. Although we have strong reason to suspect that TMI are important in plant communities, in only a few cases has this been explicitly demonstrated.

\section{Phenotypic plasticity in response to the abiotic environment}

Many studies have shown that plant species may produce a broad range of phenotypes in response to variation in the abiotic environment (Silvertown and Gordon 1989, Sultan 1993a, b, $c$, Pigliucci 2001). In one of the few experiments explicitly designed to examine the effects of plastic responses to abiotic factors on competition, Poorter and Lambers (1986) measured the outcome of competition, in environments that differed in resource fluctuations, between two inbred lines of Plantago major. One line was highly plastic in morphology and physiology and the other was restricted in plasticity. They found that, with increasing frequency of fluctuations in nutrient level, the highly plastic line outcompeted the less plastic line. This study supports the hypothesis that plastic individuals are superior competitors in temporally variable environments. Although Poorter and Lambers (1986) did not attribute differences in competitive ability to specific traits, other studies have examined the relationship between plasticity of specific traits and plant interactions. In particular, root systems are highly plastic and are fundamentally related to plant interactions. In this section, we focus on how variation in abiotic conditions may affect root systems and, thus, interactions among plants.

The proportional allocation of biomass to roots vs. shoots is fundamental to interactions among plants (Fitter 1994, Robinson 1994, Reynolds and D'Antonio 1996, Colasanti and Hunt 1997, Aerts and Chapin 1999). Among species, plants allocate proportionally more biomass to roots in nutrient-poor and water-poor environments and more biomass to shoots in light-limited environments (Chapin 1980, Ericsson 1995, Aerts 1999). This response is thought to maximize growth rate (Ägren and Ingestad 1987) and competitive ability (Crick and Grime 1987, Tilman 1988, Grime et al. 1997). In fertile, productive environments, the ability to allocate soil resources to leaf production is characteristic of highly competitive species (Grime 1979, Ryser and Notz 1996). In general, species that invest 
more in roots are thought to competitively dominate habitats with low productivity, and those that invest more in shoots are thought to competitively dominate habitats with high productivity (Tilman 1988).

Despite the importance of root: shoot ratios to a plant's performance, plasticity in root: shoot ratios may provide a relatively poor predictor of competitive ability. Reynolds and D'Antonio (1996) found no consistent relationship between experimentally induced differences in root mass ratio (root mass divided by total plant mass) and competitive ability. Of eight relevant studies, three found that the least plastic species was the most competitive (Zangerl and Bazzaz 1983, Aerts et al. 1991, Dakheel et al. 1993), one found that the most plastic species was the best competitor (McGraw and Chapin 1989), and four found no relationship between plasticity in root mass ratio and competitive ability (Gurevitch et al. 1990, Wilson 1991, Cheplick 1995, Figiel et al. 1995). It may be that differences in the mass of roots and shoots are less important than finer details in root and shoot morphology and physiology (Aerts et al. 1991).

Root systems can show considerable plasticity in absorptive capacity, total surface area, mass to surface area ratios, rooting density, the timing of growth and placement, and architecture (Biswell 1935, Muller 1946, Drew and Saker 1975, Jackson and Caldwell 1989, Callaway 1990, Kolb et al. 1990, Pregitzer et al. 1993, Fitter 1994, Jackson et al. 1990). Caldwell and Richards (1986) surmised that high rooting density and root thickness would be advantageous for competitive potential, but little is known about the effect of such plasticity on plant interactions. Using data-based models, Jackson and Caldwell (1996) estimated that plasticity in root proliferation and nutrient uptake rates in resource-rich patches increased nitrogen and phosphorus acquisition from $28 \%$ to $70 \%$. Confirming the hypothesis that plastic responses to resource availability should provide a competitive advantage, empirical studies in the system used to develop Jackson and Caldwell's model indicated that belowground plasticity in root morphology and root: shoot ratios of Pseudoroegneria spicata improved its ability to withstand competition from the more vigorous, but less plastic Agropyron desertorum (Huber-Sannwald et al. 1996).

Typically, genotypic variation in root architecture is thought to reduce niche overlap and, therefore, competition among species (Parrish and Bazzaz 1976, Cody 1986). However, plastic responses to abiotic conditions could also increase competitive interactions if the result is a high overlap of rooting zones (Silvertown and Gordon 1989). In a review of root form and depth distribution, Richards (1986) observed that the development of deep taproots vs. wide-spreading lateral roots of phreatophytic plants (species that typically utilize deep ground water) was dependent on environmental conditions such as the depth to the water table. Such root architectural plasticity could either increase or decrease competition depending on whether or not the target plant adopted a morphology that caused rooting zones to overlap with neighbors.

Studies of Quercus douglasii (blue oak) provide a good example of how root plasticity can mediate competition with neighbors (Fig. 1). Quercus douglasii dominates a wide range of habitats in California, USA, including the mesic fringes of grasslands in the Central Valley, transitional vegetation near the Great Basin, the Sierra Nevada foothills, and throughout the coastal Santa Lucia Mountains. Based on predawn water stress and stable isotope analyses, individuals of $Q$. douglasii vary at the scale of meters with regard to utilization of the water table (Lewis and Burghy 1964, Griffin 1973, Callaway et al. 1991). Callaway et al. (1991) measured predawn water potentials and fine roots in the upper $50 \mathrm{~cm}$ of soil of $24 Q$. douglasii individuals and found evidence for two basic architectural patterns. Some trees had high water potentials $(-1.5$ to -3.0 $\mathrm{MPa}$ at the end of the dry season) and a low biomass of fine roots in the shallow soil beneath their canopies, whereas other trees had low water potentials $(-3.5$ to $-4.5 \mathrm{MPa}$ ) and approximately five times greater fine root biomass near the surface (Fig. 1). These data suggest that some trees do not access the water table (very low water potentials) and develop a dense root system near the surface, whereas other trees access the water table and do not invest as much in root biomass near the surface. These architectural differences were not definitively produced by phenotypic plasticity (i.e., Callaway did not manipulate root morphologies in genetically identical oak trees); however, neither examination of leaf and acorn characteristics nor isozyme analysis suggested genetic differences between the two groups of trees (Callaway 1990). Furthermore, controlled experiments with seedlings demonstrated a high degree of plasticity in lateral root development (Callaway 1990). When the taproots of $Q$. douglasii seedlings were grown into dry substrate $30 \mathrm{~cm}$ below moist topsoil, lateral root biomass in topsoil increased by $80 \%$ and lateral root number by $>50 \%$ over the fivemonth experimental period compared to seedlings with access to damp, deeper soils, which invested most of their root biomass into deep taproots. Thus, it is likely that the differences in root architecture among adult trees reflect a similar plastic response that is cued by the accessibility of the water table to the root system, and are not due to genetic differences among trees.

Variation in root architecture has substantial consequences for the plant communities associated with $Q$. douglasii. In the field, the biomass of the herbaceous understory beneath trees with shallow root systems was $\sim 50 \%$ lower than the biomass in surrounding open grassland, indicating a strong competitive effect of shallow tree roots. In contrast, the biomass of plants under trees that had accessed the water table was approximately two times greater than the biomass in open grassland (four times greater than under shallow-rooted 


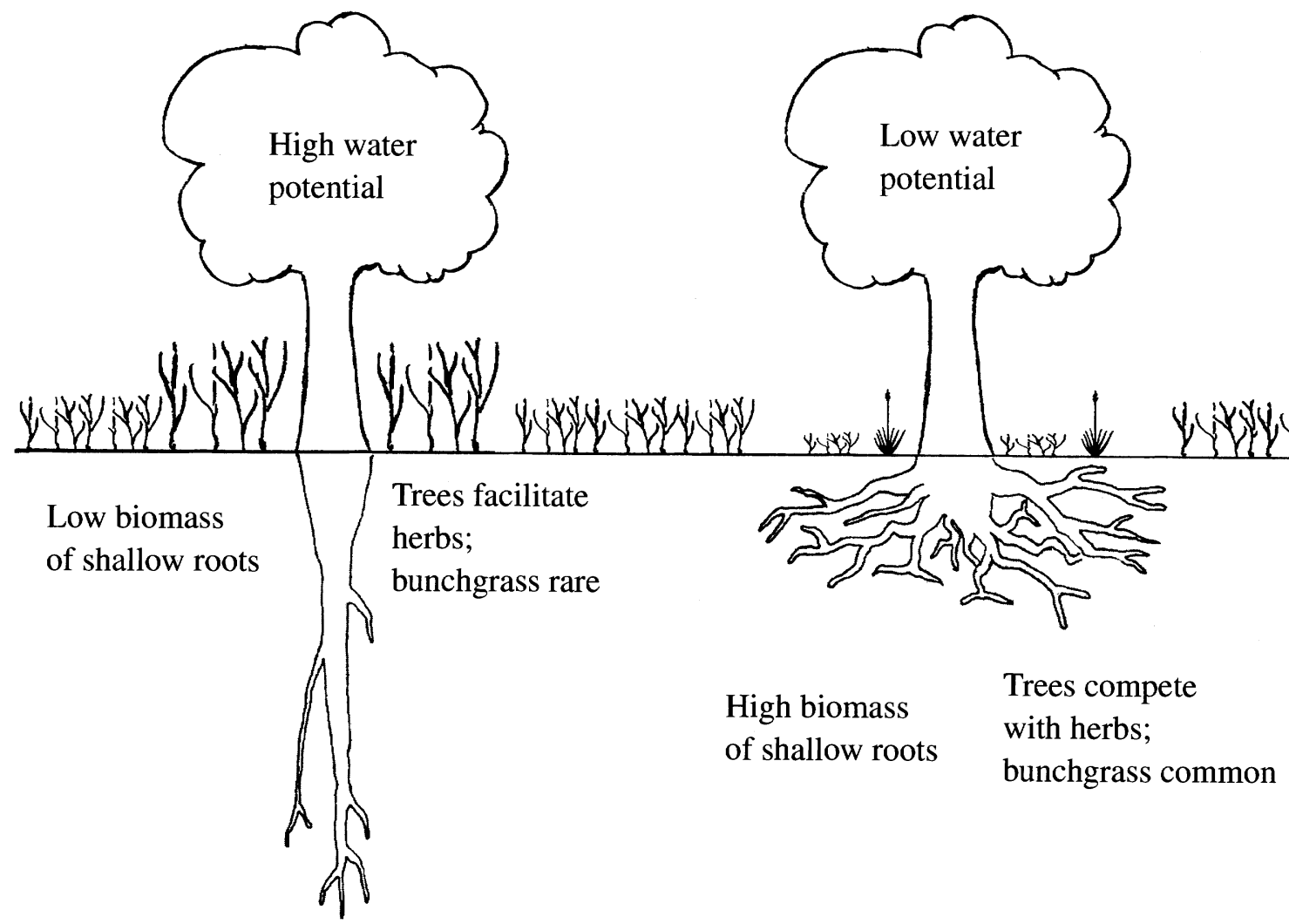

FIG. 1. Interactions between oaks and understory herbs vary depending on plastic responses of oaks to water. Oaks that are able to access the water table have high water potentials, few shallow roots, and facilitate understory herbs by adding litter and nutrients leached from foliage by rain. Oaks that cannot access the water table have low water potentials, many shallow roots, and compete with understory herbs. The native bunchgrass Stipa pulchra is much more common under shallowrooted oaks than under deep-rooted oaks.

trees), indicating a facilitative effect. This facilitative effect was due to nutrients added through litter fall and precipitation filtering through the tree canopies. Experiments confirmed that only shallow-rooted trees competed with understory grasses. When tree roots were experimentally excluded under shallow-rooted trees, the biomass of grasses almost doubled, but root exclosures under deep-rooted trees had no effect on grasses. In addition to affecting productivity, the plasticity of $Q$. douglasii root systems also affected the species composition of the understory community (Callaway et al. 1991). In savannas, the native bunchgrass Stipa pulchra constituted $<0.5 \%$ of the biomass beneath deep-rooted trees. In contrast, the biomass of $S$. pulchra under shallow-rooted trees was $3.9 \%$ of the total herbaceous understory.

Theory predicts that plasticity in behavior, defined broadly to include plastic morphologies of plants (Silvertown and Gordon 1989) can transmit heterogeneity from the environment to the population or community (Chesson and Rosenzweig 1991). These studies on $Q$. douglasii provide one of the few documented examples of this phenomenon for plants; however, similar effects are likely to occur whenever variation in access to re- sources strongly modifies the architecture of root systems.

Root systems also affect some types of facilitative interactions by redistributing water laterally and vertically throughout the soil profile. In 1929, Magistad and Breazeale hypothesized that deep-rooted plants that maintained some living roots near the surface might extract water far below the surface, but lose a portion of this water into dry soils at the surface. Since then, the passive redistribution of soil water along gradients of water potential through root systems (hydraulic lift) has been shown for many species, including Q. douglasii (Ishikawa and Bledsoe 2000), in a wide variety of conditions (Caldwell et al. 1998). Hydraulic lift may benefit individual plants by allowing them to cache water in shallow soils during the night and increase their total daily transpiration rates the following day (Caldwell and Richards 1989). Facilitation of neighboring individuals may occur when cached water at the surface becomes available to other plants (Caldwell 1990, Dawson 1993). A form of hydraulic lift, or "water transfer" has also been described at a far smaller scale (centimeters) in the soil (Corak et al. 1987), raising the possibility of much broader impacts of root 


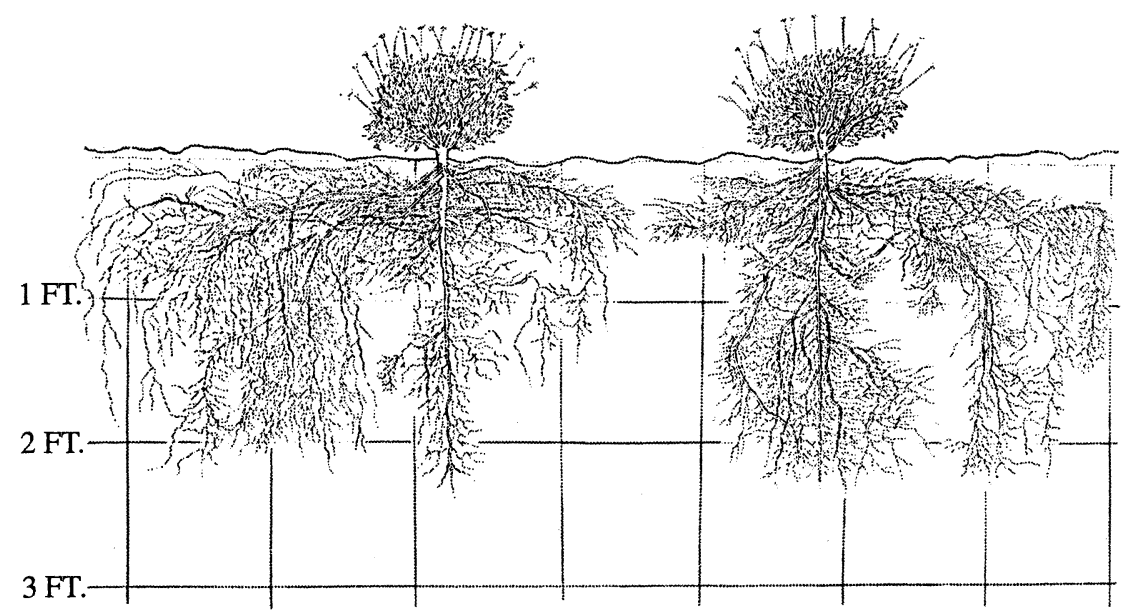

FIG. 2. Root architecture of excavated Paarthenium argentatum (guayule) plants (Muller 1946). At the time of excavation, the plants were 17 months old and lacked other nearby neighbors. Note the reduced spread of root toward the conspecific neighbor. (Units: 1 foot $[\mathrm{ft}] \approx 30.5 \mathrm{~cm}$.)

plasticity on water movement in soils. Although we are not aware of any studies that have clearly linked plasticity in root system architecture to differing effects on neighbors via hydraulic lift, this would be a fruitful area for future research.

Although we have focused primarily on plasticity of roots, abiotic factors also induce plastic responses by shoots and leaves (e.g., Cipollini 1997, 1999). We are unaware of studies that have addressed how these responses affect interactions among plants, but effects are likely and further research in this area is warranted.

\section{Phenotypic plasticity in response to neighboring plants}

Neighboring plants cause dramatic phenotypic responses in many plant species. For example, Rice et al. (1993) grew Quercus douglasii seedlings in three different plant communities. Morphological traits differed and water use efficiencies were higher for seedlings grown with annuals than for those grown with perennials. Soil water depletion was more rapid in annual plant communities, suggesting that plasticity in water use efficiency may have been adaptive, enhancing the competitive ability of oak seedlings. Clonal plants provide many examples of plastic responses to neighbors (Hutchings and Slade 1988, Hutchings and DeKroon 1994). Turkington (1991; also see Turkington 1983) found that the morphology of Trifolium repens responded plastically to the presence of different grass species. Moreover, the plastic response of $T$. repens clones to different grass species in the greenhouse depended on which species the clone had previously been associated with in the field. Furthermore, T. repens responded differently to the presence of root systems of three different grass species (Turkington 1990). Because grass shoots were removed in this study, the plastic responses of $T$. repens were not likely to have been caused through effects on aboveground resources.
The presence and identity of neighboring plants can also induce plastic responses in root allocation and architecture. Root plasticity in response to neighbors is striking in natural communities (Fig. 2; see Muller 1946, Nye and Tinker 1977, D'Antonio and Mahall 1991, Brisson and Reynolds 1994, Mou et al. 1995) and agricultural settings (Schenk et al. 1999). Experimental analyses indicate that neighbors may affect the phenotypic expression of root systems in two fundamentally different ways: either through direct effects on soil resources, or independently of soil resources. In the first case, the roots of neighbors alter belowground resource availability and therefore affect neighbors in much the same way as variation in abiotic resources (Crick and Grime 1987, Robinson and Rorison 1988). Clearly, many plant species can concentrate their roots in small patches of high resources and reduce proliferation in resource-poor patches (Wiersum 1958, Drew and Saker 1975, Jackson and Caldwell 1989, Caldwell et al. 1991). Because different species differ in resource uptake abilities, neighbor identity can have large effects on responses to resource patches. For example, Jackson and Caldwell (1996) found that the proliferation of roots of Artemisia tridentata in resource-rich patches was much greater when the patch was shared with Pseudoroegneria spicata than when shared with Agropyron desertorum. Similarly, in the field, D'Antonio and Mahall (1991) found that two chaparral shrub species had markedly lower root lengths and occupied less soil volume when they were interacting with a superior competitor for water, Carpobrotus edulis.

The assumption that root plasticity caused by neighboring plants operates through this first mechanism has important consequences for the theoretical relationship between plasticity and competitive ability and for theory on processes that organize plant communities. If root plasticity caused by neighboring plants is primar- 
ily determined by resource limitations, then superior competitors ought to be more plastic than poor competitors because plasticity allows for the rapid projection of resource-capturing roots into nutrient-rich soil patches (Fitter and Hay 1981, Crick and Grime 1987). Taking this perspective a step farther, plasticity-and therefore competitive ability - should be more important in more productive communities where high rates of resource exploitation create localized zones of depletion (Crick and Grime 1987).

As previously described, there is a substantial body of literature that supports the role of resources in neighbor interactions and root phenotypic plasticity (see also Bookman and Mack 1982, Fitter 1986, Gordon et al. 1989, Nobel 1997). However, there is also evidence that many plant species affect the root morphology of their neighbors independently of effects on soil resources (Lund 1947, Dicke and Sabelis 1988, Miller and Gow 1989, Mahall and Callaway 1992, 1996, Stenz and Weisenseel 1993, Krannitz and Caldwell 1995, Schenk et al. 1999). In 1907, Schreiner and Reed found that roots of Lolium perenne would grow away from the roots of other conspecific individuals. However, when they added "carbon black" to the substrate, roots intermingled. More recently, activated carbon, which adsorbs charged organic molecules and is probably similar to the carbon black of Schreiner and Reed, has been shown to ameliorate the negative effects of Larrea tridentata roots on the root elongation of conspecifics and of Ambrosia dumosa roots (Mahall and Callaway 1991, 1992; see also Brisson and Reynolds 1994). Similar ameliorating effects of activated carbon have been documented for Centaurea maculosa root systems on the root elongation of Festuca idahoensis (Ridenour and Callaway 2001). These results suggest that chemicals exuded from the roots of one species can alter root growth, distribution; and architecture of other species (Schenk et al. 1999). Presumably, by reducing overlap of root systems, these root avoidance mechanisms reduce competition.

A recent experiment by Gersani et al. (2001) provides a contrasting example of the potential consequences of neighbor-induced plasticity of root growth. Gersani and colleagues compared the growth and reproduction of Glycine max (soybean) plants with sole possession of the rooting zone to those of plants sharing the rooting zone with a conspecific. They found that sharing individuals produced $85 \%$ more root mass than non-sharing plants. Virtually all other work on root plasticity has demonstrated inhibitory effects resulting in avoidance and spatial segregation of root systems. In contrast, G. max plants appeared to proliferate roots aggressively to contest resources when they were forced to share the rooting zone with another plant. The increase in root growth in response to neighbors contradicts theoretical models of nutrient foraging that emphasize reduced root growth in response to low nu- trient levels, which would be expected where roots are dense.

Although there are many examples of plastic growth responses of plants in response to neighbors, the consequences of this plasticity have been addressed in only a few cases. Perhaps the best examples are those of plasticity in stem elongation, clonal architecture, and photosynthetic chemistry. High densities of neighbors often have dramatic effects on the aboveground plasticity of biomass allocation, leaf morphology, and stem elongation. Phytochrome-mediated stem elongation in response to the red : far red ratio is a well-documented example of density-dependent plasticity (Dudley and Schmitt 1995, 1996). Chlorophyll absorbs light in the red region of the spectrum and therefore low red : far red indicates the presence of neighbors and triggers stem elongation in many species of plants. As part of the "shade avoidance response," stem elongation enhances fitness by increasing light interception under competitive conditions. Because stem elongation occurs in response to the red : far red ratio rather than to the amount of photosynthetically available radiation, it is possible to induce stem elongation without altering light availability, thereby decoupling the cue from the resource (Schmitt et al. 1999). Dudley and Schmitt $(1995,1996)$ tested the adaptive value of plasticity in stem elongation by using this technique and transplanting manipulated phenotypes of the same genotype of Impatiens capensis into different competitive environments. They found that elongated phenotypes were more fit at a high density of conspecific neighbors than non-elongated phenotypes, but that non-elongated phenotypes were more fit at low neighbor densities. Moreover, Schmitt et al. (1995) found that transgenic tobacco plants in which elongation responses to shade had been disabled had decreased fitness when grown in competition with wild-type plants with intact elongation responses. They also found that constitutively elongated Brassica ein plants had lower fitness, relative to a non-elongated wild type, at low densities than in competition with the elongated wild type at high density. Their findings that phytochrome-mediated elongation is advantageous when competing in dense stands indicates that phenotypic plasticity can increase a species' tolerance to competition. Harley and Bertness (1996) induced elongated and non-elongated morphologies of four species of marsh plants by growing plants in different density treatments. Plants grown at high density developed slender, elongated stems that approached or exceeded their theoretical maximum heights based on mechanical considerations. Elongated plants depended on neighbors for physical support and often suffered stem failure if neighbors were removed, indicating that elongated plants interacted positively with neighbors in a way that non-elongated plants did not. These studies indicate that phenotypic plasticity in stem elongation can change the nature of interactions 
among individual plants and improve performance in a competitive context.

Similarly, studies on Abutilon theophrasti showed differential patterns of plasticity in response to neighbors. In soybean fields, competition is initially low for Abutilon and intensifies later in the season. Populations of Abutilon from soybean fields demonstrated selection for increased elongation at later nodes when they could overtop surrounding soybeans. In contrast, late elongation was selected against in cornfield Abutilon populations because no individuals were able to overtop the corn (Weinig 2000a). The onset of competition varied with the species of competitor, and the fitness benefits of elongation therefore also depended on the timing of the plastic response. These population differences suggest that there is adaptive response to different competitive environments and that different life history stages can have different levels of phenotypic plasticity (Weinig 2000a, b, Weinig and Delph 2000).

Finally, an excellent example of the adaptive value of plasticity in clonal architecture comes from studies of the clonal plant Ranunculus reptans (Van Kleunen and Fischer 2001). Genotypes of Ranunculus varied in their plastic responses (changes in stolon length and growth angle) to the presence of a competitor: those from habitats containing competitors were more plastic than those from habitats where Ranunculus grew alone. When grown in experimental habitats with and without competitors (Agrostis stolonifera), the more plastic genotypes had a higher fitness, averaged over both habitats, than the less plastic genotypes. Whether the more plastic genotypes also had greater competitive effects on Agrostis was not tested.

These studies generally indicate that plastic responses to competitors reduce competition, in concordance with theoretical predictions that increasingly flexible "behavior," defined broadly to include morphological plasticity (Silvertown and Gordon 1989) increases the probability of coexistence of species (Chesson and Rosenzweig 1991). Similarly, forest models that allow plastic development of individual canopies in response to neighbors predict that plasticity promotes overall stand productivity by reducing competition (SorrensenCothern et al. 1993).

The photosynthetic chemistry of plants can be as plastic as leaf and stem morphology (Pearcy 1999); however, little is known about how plasticity in photosynthesis correlates with competitive ability. In general, fast-growing species adapted to high light conditions (which are often superior competitors) are more plastic in their maximum photosynthetic capacity than slow-growing, shade-tolerant species (Strauss-Debenedetti and Bazzaz 1996). Species with plastic photosynthetic responses should be able to persist in a wide variety of environments. This plasticity in photosynthetic chemistry and leaf morphology appears to allow the seedlings of some species to benefit from "nurse plants" in harsh environments. For example, in some
Californian woodlands Quercus agrifolia seedlings are more common under shrubs than in the open grassland, and experiments indicate that seedling survival is higher under shrubs than in the open (Callaway and D'Antonio 1991). The effects of the shade from shrubs appear to be somewhat conditional, as shrubs and $Q$. agrifolia seedlings are highly associated in south-facing savanna communities, but much less so in northfacing woodland communities (Callaway and Davis 1999).

\section{Plasticity in response to herbivory}

Herbivory triggers plastic responses in morphology, reproduction, and tissue chemistry in many plant species. Herbivory almost always places a plant at a competitive disadvantage (Strong et al. 1984, Louda et al. 1990, Crawley 1992) because of the carbon and resource costs of losing biomass. In contrast to the effects of biomass loss, little is known about how herbivoreinduced plasticity affects plant interactions. What is known about the responses stimulated by herbivory (the induction of plant resistance, compensatory growth, and increased resource uptake) suggests that plasticity affects interactions among plants in ways that cannot always be predicted on the basis of simple biomass losses alone.

Some of the best documented plastic responses of plants are the induction of morphological and chemical traits that confer resistance to herbivores and pathogens (Harvell 1990, Myers and Bazely 1991, Baldwin 1999). The negative effects of induced resistance on herbivores and pathogens have been well documented and reviewed (Karban and Myers 1989, Karban and Baldwin 1997, Agrawal et al. 1999, Baldwin 1999), and we will not discuss effects on consumers further except to point out that the dynamic consequences of induced resistance on communities of multiple consumers will depend, in part, on whether induced resistance is specific to particular consumers or general (Karban and Baldwin 1997, Bolker et al. 2003).

Here, we will focus on the effects of induced resistance on interactions among plants, i.e., trait-mediated indirect interactions (TMII; Werner and Peacor 2003) between herbivores and nonconsumed plants in the community. To explain why resistance is plastic (inducible) and not constitutive (always present at high levels), most theories postulate that growth or reproductive costs exist, but that they can be minimized by deploying resistance mechanisms only when they are needed (Karban and Myers 1989, Harvell 1990, Zangerl and Bazzaz 1992; but see Adler and Karban 1994). Attempts to document the fitness costs of resistance in plants have had mixed success (Simms and Rausher 1987, Baldwin et al. 1990, Simms 1992, Karban 1993, Adler and Karban 1994, Sagers and Coley 1995, Mauricio 1997, Mauricio and Rausher 1997, Zangerl et al. 1997, Agrawal 1998, Baldwin 1998, Siemens and Mitchell-Olds 1998, Heil et al. 2000, Redman et al. 
2001, Koricheva 2002). However, costs of resistance are clear in at least some cases, and in theory should reduce the ability of a plant to compete with its neighbors (Herms and Mattson 1992). Karban (1993) examined the costs of induced resistance in a desert shrub in combination with factorial manipulations of neighbors, but costs of induced resistance were not detectable in this system and so did not interact with neighbor treatments. In contrast, recent studies with wild tobacco found that induced plants had less of a competitive effect on neighbors than did uninduced plants, and that induced plants had larger costs of induced resistance in the presence than in the absence of competitors (Van Dam and Baldwin 1998, Baldwin and Hamilton 2000). This suggests that induced resistance can reduce both the effect and response components (Goldberg 1990) of competitive ability. Agrawal (2000) also found that costs of induced resistance in an annual herb were higher, and competitive effects on neighbors were reduced, when induced plants were grown at high vs. low densities. In contrast, Cipollini (2002) found no effect of competition on costs of induced defenses in Arabadopsis, probably because plants experiencing competition did not increase their defenses to the same degree as did control plants.

Siemens et al. (2002) studied the costs of secondary metabolite production by Brassica rapa in the presence and absence of the generalist competitor Lolium perenne. They used artificial selection and herbivore-induction treatments to produce genetic and environmental variation in concentrations of the defense chemicals myrosinase and glucosinolate in different genetic lines of B. rapa. In contrast to theoretical predictions, the costs of defense that occurred in the absence of competitors did not occur in the presence of competitors. The breakdown products of the glucosinolatemyrosinase reaction appeared to also function as allelopathic agents (see also Bell and Muller 1973), which may have benefited $B$. rapa plants in competition, but not when alone, and may have reduced the costs of chemical production. In general, activated carbon treatments designed to neutralize allelopathic effects restored costs in competition treatments. Others have found evidence for dual antiherbivore/allelopathic roles in inducible plant metabolites (Lovett and Hoult 1995, Tang et al. 1995), and Callaway et al. (1999) found that exudation of some compounds from the roots of Centaurea maculosa increased after moderate leaf herbivory. Centaurea maculosa roots are allelopathic (Ridenour and Callaway 2001), and root herbivory increases the exudation of (-)-catechin, a phytotoxic chemical (R. M. Callaway and J. Vivanco, unpublished data). If secondary compounds that provide resistance to herbivory commonly have dual roles as allelopathic agents, then induced resistance to herbivores might routinely increase negative allelopathic interactions with neighbors. If so, this could partially offset any reduced competitive ability caused by the costs of production of the secondary compounds.

The growth rates of some plant species are plastic in response to herbivory. Herbivory often increases growth rates and, in some cases, may even stimulate "overcompensation," i.e., larger final biomass or enhanced reproduction, although this latter concept is highly controversial (Paige and Whitham 1987, MüllerSchärer 1991, Trumble et al. 1993, Frank et al. 2002). Agrawal (2000) found that induced Lepidium virginicum plants overcompensated in biomass even though they also induced defenses. Similarly, the invasive weed, Centaurea maculosa, demonstrates a remarkable indifference to herbivory and defoliation (MüllerSchärer 1991, Callaway et al. 1999). Although the mechanisms for compensatory grown in C. maculosa are not fully understood, fine-root growth of this plant increases with herbivory (Steinger and Müller-Schärer 1992). Although it is reasonable to hypothesize that the phenomenon of plastic compensatory growth increases resource uptake and therefore competitive impacts on neighbors, to our knowledge no studies have investigated this possibility.

Finally, if consumers alter the morphology of the plant, they may have large effects on species that use plants as habitat. For example, infection by dwarf mistletoe (Arceuthobium spp.) alters tree allocation patterns by inducing massive "brooms," and consequently increases the density and diversity of forest insects and birds (Stevens and Hawksworth 1970, Scharpf 1975, Bennetts et al. 1996).

\section{CONCLUSIONS}

Plastic responses of plants to the abiotic environment, neighbors, and herbivory can result in genetically identical individuals that have very different phenotypes. We have argued that these phenotypic differences should have broad implications for how plants interact with their neighbors. We acknowledge, however, that this view is likely to be controversial, considering that many plant ecologists argue that even differences among species, let alone differences within species, are largely irrelevant to interactions (Goldberg and Werner 1983, Gaudet and Keddy 1988, Hubbell 2001). Present data cannot conclusively adjudicate between these different viewpoints: in contrast to work with animal communities, where a great deal is known about TMI, at least using short-term measures (Bolker et al. 2003, Dill et al. 2003, Werner and Peacor 2003), we know relatively little about the consequences of plasticity for interactions among plants. In large part, this inequality has arisen because of the experimental difficulties in assessing the impacts of phenotypic plasticity in plants. In particular, (1) it is difficult to separate the effects of plasticity from the confounding effects of the treatments used to create plasticity (Bolker et al. 2003), and (2) it is difficult to assess the consequences of plasticity in a natural setting because of the very 
nature of plasticity: plants continue to change after they have been manipulated (Sultan 2000). Recent developments in experimental design and technology have begun to overcome these difficulties (Schmitt et al. 1999). One promising approach is to manipulate plant morphology using signals of environmental conditions rather than the actual environmental conditions, thus decoupling the plastic response from the environmental context. For example, red : far red light ratios can be used to induce "high-density" stem morphologies without actually subjecting plants to increased competition (Dudley and Schmitt 1995, 1996, Dorn et al. 2000). The presence of root exudates can be manipulated with activated charcoal without changing the density of competitors (Siemens et al. 2002). Similarly, stem elongation can be induced with gibberellic acid in the absence of competition (Cippollini and Schultz 1999), and plant resistance can be induced with jasmonic acid without actually damaging plants (Baldwin 1999). Another promising approach is the use of transgenic plants that lack the ability to induce plastic responses (Schmitt et al. 1995). Application of these and similar techniques in future research should allow us to make great strides toward understanding the consequences of phenotypic plasticity in natural communities. We suggest profitable research directions for each of our three major categories of plasticity. In each case, because plasticity should be most advantageous when environmental heterogeneity is high (Silvertown and Gordon 1989), TMI among plants should be most important among species experiencing a wide range of environmental conditions.

Plasticity induced by the abiotic environment.-Because variation in the abiotic environment may lead to variability in plant phenotype, the nature of plant interactions may vary across the landscape in concert with abiotic factors. As indicated by work on the rooting morphology of oaks, the effects can be as striking as reversing the sign of interactions from negative to positive. Many of these TMI probably have been overlooked because variation in belowground resources is not immediately apparent to ecologists. Collaborations between ecologists and earth scientists would be likely to uncover a pervasive suite of mechanisms whereby "hidden" abiotic variation resulted in TMI between plants and neighbors across superficially homogenous landscapes. Because groundwater availability can be highly heterogeneous and has large effects on root morphology, an obvious first step would be to better explore the link between hydrology and TMI.

Plasticity induced by neighbors.-It is well established that neighbors affect plant morphology. Various techniques that allow us to manipulate plant morphology without altering the biotic environment are now available, as we have described. We need a suite of studies using these techniques to determine the importance of neighbor-induced plasticity in mediating interactions among plants. We predict that these studies will reveal that TMI are widespread and that they generally serve to reduce competitive interactions between plants. Because some of the plastic responses of plants to neighbors are apparently species specific, interaction coefficients among plants may change as a function not only of neighbor density, but also of neighbor identity, lending a new level of complexity to plant community theory.

Plasticity induced by consumers.-Plastic responses of plants to consumers are common and can involve both chemical and morphological responses. The consequences of induced resistance for interactions with consumers have been well documented and are reviewed elsewhere (Karban and Baldwin 1997, Agrawal et al. 1999). Theoretical considerations suggest that induced responses to consumers should reduce the competitive ability of induced plants, creating TMII between herbivores and nonconsumed plants in the community. Recent advances in understanding of plant wound signals now allow us to manipulate the plant phenotype in the absence of differences in tissue damage, as previously described. We need a suite of such studies to examine herbivore-induced TMI. Such studies also are likely to make major contributions to the debate over whether defenses against consumers have costs, because they can assess potential costs in a variety of environments.

\section{ACKNOWLEDGMENTS}

We thank Frederick Adler, Steve Franks, Jonathan Rothman, Giles Thelen, Heather Tone, and two anonymous reviewers for helpful comments on the manuscript and other assistance. We thank the Georgia Coastal Ecosystems LTER (OCE 99-82133, S. C. Pennings and C. L. Richards) and the Andrew W. Mellon foundation (R. M. Callaway) for financial support. This is contribution number 830 from the University of Georgia Marine Institute.

\section{Literature Cited}

Adler, F. R., and R. Karban. 1994. Defended fortresses or moving targets? Another model of inducible defenses inspired by military metaphors. American Naturalist 144: 813-832.

Aerts, R. 1999. Interspecific competition in natural plant communities: mechanisms, trade-offs and plant-soil feedbacks. Journal of Experimental Botany 50:29-37.

Aerts, R., R. G. A. Boot, and P. J. M. van der Aart. 1991. The relation between above- and belowground biomass allocation patterns and competitive ability. Oecologia 87: 551-559.

Aerts, R., and F. S. Chapin, III. 1999. The mineral nutrition of wild plants revisited: a re-evaluation of processes and patterns. Advances in Ecological Research 29:216-244.

Agrawal, A. A. 1998. Induced responses to herbivory and increased plant performance. Science 279:1201-1202.

Agrawal, A. A. 2000. Benefits and costs of induced plant defense for Lepidium virginicum (Brassicacae). Ecology 81: 1804-1813.

Agrawal, A. A., S. Tuzun, and E. Bent. 1999. Induced plant defenses against pathogens and herbivores: biochemistry, ecology, and agriculture. American Phytopathological Society Press, St. Paul, Minnesota, USA.

Ägren, G. I., and T. Ingestad. 1987. Root : shoot ratio as a balance between nitrogen, productivity, and photosynthesis. Plant, Cell and Environment 10:579-586. 
$\rightarrow$ Baldwin, I. T. 1998. Jasmonate-induced responses are costly but benefit plants under attack in native populations. Proceedings of the National Academy of Sciences (USA) 95: 8113-8118.

Baldwin, I. T. 1999. Inducible nicotine production in native Nicotiana as an example adaptive phenotypic plasticity. Journal of Chemical Ecology 25:3-30.

Baldwin, I. T., and W. Hamilton III. 2000. Jasmonate-induced responses of Nicotiana sylvestris results in fitness costs due to impaired competitive ability for nitrogen. Journal of Chemical Ecology 26:915-952.

Baldwin, I. T., C. L. Sims, and S. E. Kean. 1990. The reproductive consequences associated with inducible alkaloidal responses in wild tobacco. Ecology 71:252-262.

$\rightarrow$ Bell, D. T., and C. H. Muller. 1973. Dominance of California annual grasslands by Brassica nigra. American Naturalist 90:277-299.

Bennetts, R. E., G. C. White, F. G. Hawksworth, and S. E. Severs. 1996. The influence of dwarf mistletoe on bird communities in Colorado ponderosa pine forests. Ecological Applications 6:899-909.

Bertness, M. D., and R. M. Callaway. 1994. Positive interactions in communities. Trends in Ecology and Evolution 9:191-193.

Biswell, H. H. 1935. Effects of environment upon the root habits of certain deciduous forest trees. Botanical Gazette 96:676-709.

Bloom, A. J., F. S. Chapin, III, and H. A. Mooney. 1985. Resource limitation in plants-an economic analogy. Annual Review of Ecology and Systematics 16:363-392.

Bolker, B., M. Holyoak, V. Křivan, L. Rowe, and O. Schmitz. 2003. Connecting theoretical and empirical studies of traitmediated interactions. Ecology 84:1101-1114.

Bookman, P. A., and R. N. Mack. 1982. Root interaction between Bromus tectorum and Poa pratensis: a three-dimensional analysis. Ecology 63:640-646.

Bradshaw, A. D. 1965. Evolutionary significance of phenotypic plasticity in plants. Advances in Genetics 13:115155.

Bradshaw, A. D. 1973. Environment and phenotypic plasticity. Brookhaven Symposium in Biology 25:75-94.

Brisson, J., and J. F. Reynolds. 1994. The effect of neighbors on root distributions in a creosote bush (Larrea tridentata) population. Ecology 75:1693-1702.

Caldwell, M. M. 1990. Water parasitism stemming from hydraulic lift: a quantitative test in the field. Israel Journal of Botany 39:395-402.

Caldwell, M. M., T. E. Dawson, and J. H. Richards. 1998. Hydraulic lift: consequences of water efflux from the roots of plants. Oecologia 113:151-161.

Caldwell, M. M., J. H. Manwaring, and S. L. Durham. 1991. The microscale distribution of neighboring plant roots in fertile soil microsites. Functional Ecology 5:765-772.

Caldwell, M. M., and J. H. Richards. 1986. Competing root systems: morphology and models of absorption. Pages 251 273 in T. J. Givinish, editor. On the economy of form and function. Cambridge University Press, Cambridge, UK.

Caldwell, M. M., and J. H. Richards. 1989. Hydraulic lift: water efflux from upper roots improves effectiveness of water uptake from deep roots. Oecologia 79:1-5.

Callaway, R. M. 1990. Effects of soil water distribution on the lateral root development of three species of California oaks. American Journal of Botany 77:1469-1475.

Callaway, R. M. 1995. Positive interactions among plants. Botanical Review 61:306-349.

Callaway, R. M., and C. M. D'Antonio. 1991. Shrub facilitation of coast live oak establishment in central California. Madroño 38:158-169.

Callaway, R. M., and F. W. Davis. 1999. Recruitment of Quercus agrifolia in central California: the importance of shrub-dominated "gaps." Journal of Vegetation Science 9: 646-656.

Callaway, R. M., T. DeLuca, and W. M. Belliveau. 1999. Herbivores used for biological control may increase the competitive ability of the noxious weed Centaurea maculosa. Ecology 80:1196-1201.

Callaway, R. M., N. M. Nadkarni, and B. E. Mahall. 1991. Facilitating and interfering effects of Quercus douglasii in central California. Ecology 72:1484-1499.

Callaway, R. M., and S. C. Pennings. 2000. Facilitation may buffer competitive effects: indirect and diffuse interactions among salt marsh plants. American Naturalist 156:416424.

Chapin, F. S., III. 1980. The mineral nutrition of wild plants. Annual Review of Ecology and Systematics 11:233-260.

Cheplick, G. P. 1995. Genotype variation and plasticity of clonal growth in relation to nutrient availability in $\mathrm{Am}$ phibromus scabrivalvis. Journal of Ecology 83:459-468.

Chesson, P., and M. Rosenzwieg. 1991. Behavior, heterogeneity, and the dynamics of interacting species. Ecology 72:1187-1195.

Cippollini, D. F., Jr. 1997. Wind-induced mechanical stimulation increases pest resistance in common bean. Oecologia 111:84-90.

Cippollini, D. F. 1999. Costs to flowering of the production of a mechanically hardened phenotype in Brassica napus L. International Journal of Plant Sciences 160:735-741.

Cippollini, D. F. 2002. Does competition magnify the fitness costs of induced responses in Arabidopsis thaliana? A manipulative approach. Oecologia 131:514-520.

Cippollini, D. F., and J. C. Schultz. 1999. Exploring cost constraints on stem elongation in plants using phenotypic manipulation. American Naturalist 153:236-242.

Cody, M. L. 1986. Structural niches in plant communities. Pages 381-405 in J. Diamond and T. J. Case, editors. Community ecology. Harper and Row, New York, New York, USA.

Colasanti, R. L., and R. Hunt. 1997. Resource dynamics and plant growth: a self-assembling model for individuals, populations and communities. Functional Ecology 11:133145.

Corak, S. J., D. G. Blevins, and S. G. Pallardy. 1987. Water transfer in an alfalfa/maize association. Plant Physiology 84:582-586.

Crawley, M. J. 1992. Natural enemies: the population biology of predators, parasites, and diseases. Blackwell Science, Oxford, UK.

Crick, J. C., and J. P. Grime. 1987. Morphological plasticity and mineral nutrient capture in two herbaceous species of contrasted ecology. New Phytologist 107:403-414.

Dakheel, A. J., S. R. Radosevich, and M. G. Barbour. 1993. Effect of nitrogen and phosphorus on growth and interference between Bromus tectorum and Taeniarherum asperum. Weed Research 33:415-422.

D'Antonio, C. M., and B. E. Mahall. 1991. Root profiles and competition between the invasive, exotic perennial, Carpobrotus edulis, and two native shrub species in California coastal shrub. American Journal of Botany 78:885-894.

Dawson, T. E. 1993. Hydraulic lift and water use by plants: implications for water balance, performance and plantplant interactions. Oecologia 95:565-574.

Debat, V., and P. David. 2001. Mapping phenotypes: canalization, plasticity and developmental stability. Trends in Ecology and Evolution 16:555-561.

Dicke, M., and M. W. Sabelis. 1988. Infochemical terminology: based on cost-benefit analysis rather than origin of compounds? Functional Ecology 2:131-139.

Dill, L. M., M. R. Heithaus, and C. J. Walters. 2003. Behaviorally mediated indirect interactions in marine com- 
munities and their conservation implications. Ecology 84: 1151-1157.

Donohue, K., D. Messiqua, E. H. Pyle, M. S. Heschel, and J. Schmitt. 2000a. Evidence of adaptive divergence: density and site dependent selection on shade-avoidance response in Impatiens capensis. Evolution 54:1956-1968.

Donohue, K., E. H. Pyle, D. Messiqua, M. S. Heschel, and J. Schmitt. 2000b. Density dependence and population differentiation in genetic architecture in Impatiens capensis in natural environments. Evolution 54:1969-1981.

Donohue, K., E. H. Pyle, D. Messiqua, M. S. Heschel, and J. Schmitt. 2001. Adaptive divergence in plasticity in natural populations of Impatiens capensis and its consequences for performance in novel habitats. Evolution 55:692-702.

Dorn, L. A., E. Hammond Pyle, and J. Schmitt. 2000. Plasticity to light cues and resources in Arabidopsis thaliana: testing for adaptive value and costs. Evolution 54:19821994.

Drew, M. C., and L. R. Saker. 1975. Nutrient supply and the growth of the seminal root system in barley. II. Localized compensatory increases in lateral root growth and rates of nitrate uptake when nitrate is restricted to only part of the root system. Journal of Experimental Botany 26:79-90.

Dudley, S. A., and J. Schmitt. 1995. Genetic differentiation in morphological responses to simulated foliage shade between populations of Impatiens capensis from open and woodland sites. Functional Ecology 9:655-666.

Dudley, S. A., and J. Schmitt. 1996. Testing the adaptive plasticity hypothesis: density-dependent selection on manipulated stem length in Impatiens capensis. American Naturalist 147:445-465.

Emery, R. J. N., C. C. Chinnappa, and J. G. Chmielewski. 1994. Specialization, plant strategies, and phenotypic plasticity in populations of Stellaria longipes along an elevational gradient. International Journal of Plant Sciences 155: 203-219.

Ericsson, T. 1995. Growth and shoot-root ratio of seedlings in relation to nutrient availability. Plant and Soil 169:205214.

Figiel, C. R., B. Collins, and G. Wein. 1995. Variation in survival and biomass of two wetland grasses at different nutrient and water levels over a six week period. Bulletin of the Torrey Botanical Club 122:24-29.

Fitter, A. H. 1986. Spatial and temporal patterns of root activity in a species-rich alluvial grassland. Oecologia 69: 594-599.

Fitter, A. H. 1994. Architecture and biomass allocation as components of the plastic root response of root systems to soil heterogeneity. Pages 305-323 in M. M. Caldwell and R. W. Pearcy, editors. Exploitation of environmental heterogeneity by plants: ecophysiological process above- and below-ground. Academic Press, San Diego, California, USA.

Fitter, A. H., and R. K. M. Hay. 1981. Experimental physiology of plants. Academic Press, London, UK.

Frank, D. A., M. M. Kuns, and D. R. Guido. 2002. Consumer control of grassland plant production. Ecology 83:602-606.

Gaudet, C. L., and P. A. Keddy. 1988. A comparative approach to predicting competitive ability from plant traits. Nature 334:242-243.

Gersani, M., J. S. Brown, E. E. O’Brien, G. M. Maina, and Z. Abramsky. 2001. Tragedy of the commons as a result of root competition. Journal of Ecology 89:660-669.

Goldberg, D. E. 1990. Components of resource competition in plant communities. Pages 27-49 in J. B. Grace and D. Tilman, editors. Perspectives on plant competition. Academic Press, San Diego, California, USA.

Goldberg, D. E., and P. A. Werner. 1983. Equivalence of competitors in plant communities: a null hypothesis and a field experimental approach. American Journal of Botany 70:1098-1104.

Gordon, D. R., J. ·M. Welker, J. W. Menke, and K. J. Rice. 1989. Competition for soil water between annual plants and blue oak (Quercus douglasii seedlings). Oecologia 79: 533-541.

Griffin, J. R. 1973. Xylem sap tension in three woodland oaks of central California. Ecology 54:152-159.

Grime, J. P. 1979. Plant strategies and vegetation processes. John Wiley and Sons, Chichester, UK.

Grime, J. P., B. D. Campbell, J. M. L. Mackey, and J. C. Crick. 1991. Root plasticity, nitrogen capture, and competitive ability. Pages 381-397 in D. Atkinson, editor. Plant root growth: an ecological perspective. Blackwell Scientific, Oxford, UK.

Grime, J. P., J. C. Crick, and J. E. Rincon. 1986. The ecological significance of plasticity. Pages 5-29 in D. H. Jennings and A. J. Trewavas, editors. Plasticity in plants. The Company of Biologists, Cambridge, UK.

Grime, J. P., et al. 1997. Integrated screening validates primary axes of specialization in plants. Oikos 79:259-281.

Gurevitch, J., P. Wilson, J. L. Stone, P. Teese, and R. J. Stoutenburgh. 1990. Competition among old-field perennials at different levels of soil fertility and available space. Journal of Ecology 78:727-744.

Harley, C. D. G., and M. D. Bertness. 1996. Structural interdependence: an ecological consequence of morphological responses to crowding in marsh plants. Functional Ecology 10:654-661.

Harvell, C. D. 1990. The ecology and evolution of inducible defenses. Quarterly Review of Biology 65:323-340.

Heil, M., A. Hilpert, W. Kaiser, and E. Linsenmair. 2000. Reduced growth and seed set following chemical induction of pathogen defence: does systemic acquired resistance (SAR) incur allocation costs? Journal of Ecology 88:645654.

Herms, D. A., and W. J. Mattson. 1992. The dilemma of plants: to grow or defend. Quarterly Review of Biology 67:283-335.

Hubbell, S. P. 2001. The unified neutral theory of biodiversity and biogeography. Monographs in Population Biology 32. Princeton University Press, Princeton, New Jersey, USA.

Huber-Sannwald, E., D. A. Pyke, and M. M. Caldwell. 1996. Morphological plasticity following species-specific recognition and competition in two perennial grasses. American Journal of Botany 83:919-931.

Hutchings, M. J., and H. De Kroon. 1994. Foraging in plants: the role of morphological plasticity in resource acquisition. Advances in Ecological Research 25:159-238.

Hutchings, M. J., and A. J. Slade. 1988. Morphological plasticity, foraging and integration in clonal perennials. Pages 83-109 in A. J. Davy, M. J. Hutchings, and A. R. Watkinson, editors. Plant population ecology. Blackwell Scientific, Oxford, UK.

Ishikawa, C. M., and C. S. Bledsoe. 2000. Seasonal and diurnal patterns of soil water potential in the rhizosphere of blue oaks: evidence for hydraulic lift. Oecologia 125: 459-465.

Jackson, R. B., and M. M. Caldwell. 1989. The timing and degree of root proliferation in fertile-soil microsites for three cold-desert perennials. Oecologia 81:149-153.

Jackson, R. B., and M. M. Caldwell. 1996. Integrating resource heterogeneity and plant plasticity: modeling nitrate and phosphate uptake in a patchy soil environment. Journal of Ecology 84:891-903.

Jackson, R. B., J. H. Manwaring, and M. M. Caldwell. 1990. Rapid physiological adjustment of roots to localized soil enrichment. Nature 344:58-60.

Karban, R. 1993. Costs and benefits of induced resistance and plant density for a native shrub, Gossypium thurberi. Ecology 74:9-19. 
Karban, R., and I. T. Baldwin. 1997. Induced responses to herbivory. University of Chicago Press, Chicago, Illinois, USA.

Karban, R., and J. H. Myers. 1989. Induced plant responses to herbivory. Annual Review of Ecology and Systematics 20:331-348.

Kolb, T. E., K. C. Steiner, L. H. McCormick, and T. W. Bowersox. 1990. Growth response of northern red-oak and yellow-poplar seedlings to light, soil moisture and nutrients in relation to ecological strategy. Forest Ecology and Management 38:65-78.

Koricheva, J. 2002. Meta-analysis of sources of variation in fitness costs of plant antiherbivore defenses. Ecology 83: 176-190.

Krannitz, P. G., and M. M. Caldwell. 1995. Root growth responses of three Great Basin perennials to intra- and interspecific contact with other roots. Flora 190:161-167.

Levine, J. M., J. S. Brewer, and M. D. Bertness. 1998. Nutrients, competition and plant zonation in a New England salt marsh. Journal of Ecology 86:285-292.

Lewis, D. C., and R. H. Burghy. 1964. The relationship between oak tree roots and groundwater in fractured rock as determined by tritium tracing. Journal of Geophysical Research 69:2579-2588.

Louda, S. M., K. H. Keeler, and R. D. Holt. 1990. Herbivore influences on plant performance and competitive interactions. Pages 413-444 in J. B. Grace and D. Tilman, editors. Perspectives on plant competition. Academic Press, New York, New York, USA.

Lovett, J. V., and A. C. H. Hoult. 1995. Allelopathy and selfdefense in barley. Pages 170-183 in Inderjit, K. M. M. Dakshini, and F. A. Einhellig, editors. Allelopathy. American Chemical Society, Washington, D.C., USA.

Lund, E. J. 1947. Bioelectric fields and growth. University of Texas Press, Austin, Texas, USA.

Magistad, O. C., and J. F. Breazeale. 1929. Plant and soil water relations at and below the wilting percentage. Arizona Agricultural Experiment Station Technical Bulletin. Volume 29, Tuscon, Arizona, USA.

$\rightarrow$ Mahall, B. E., and R. M. Callaway. 1991. Root communication among desert shrubs. Proceedings of the National Academy of Sciences (USA) 88:874-876.

Mahall, B. E., and R. M. Callaway. 1992. Root communication mechanisms and intracommunity distributions of two Mojave Desert shrubs. Ecology 73:2145-2151.

Mahall, B. E., and R. M. Callaway. 1996. Geographic and genetic contributions to root communication in Ambrosia dumosa. American Journal of Botany 83:93-98.

Mauricio, R. 1997. Costs of resistance to natural enemies in field populations of the annual plant Arabidopsis thaliana. American Naturalist 151:20-28.

Mauricio, R., and M. D. Rausher. 1997. Experimental manipulation of putative selective agents provides evidence for the role of natural enemies in the evolution of plant defense. Evolution 51:1435-1444.

Mazer, S. J., and C. T. Schick. 1991. Constancy of population parameters for life history and floral traits in Raphanus sativus L. I. Norms of reaction and the nature of genotype by environment interactions. Heredity 67:143-156.

McGraw, J. B., and F. S. Chapin, III. 1989. Competitive ability and adaptation to fertile and infertile soils in two Eriophorum species. Ecology 70:736-749.

Miller, A. L., and N. A. R. Gow. 1989. Correlation between root-generated ion circulation and root development. Physiologia Plantarum 75:102-108.

Miller, T. E. 1994. Direct and indirect species interactions in an early old-field plant community. American Naturalist 143:1007-1025.

Mou, P., R. J. Mitchell, and R. H. Jones. 1995. Spatial distribution of roots in sweetgum and loblolly pine monocul- tures and relations with aboveground biomass and soil nutrients. Functional Ecology 9:689-699.

Muller, C. H. 1946. Root development and ecological relations of guayule. USDA Technical Bulletin 923, Washington, D.C., USA.

$\rightarrow$ Müller-Schärer, H. 1991. The impact of root herbivory as a function of plant density and competition: survival, growth and fecundity of Centaurea maculosa in field plots. Journal of Applied Ecology 28:759-776.

Myers, J. H., and D. Bazely. 1991. Thorns, spines, prickles, and hairs: are they stimulated by herbivory and do they deter herbivores? Pages 325-345 in D. W. Tallamy and M. J. Raupp, editors. Phytochemical induction by herbivores. John Wiley and Sons, New York, New York, USA.

Nobel, P. S. 1997. Root distribution and seasonal production in the northwestern Sonoran Desert for a $\mathrm{C}_{3}$ subshrub, a $\mathrm{C}_{4}$ bunchgrass, and CAM leaf succulent. American Journal of Botany 84:949-955.

Nye, P. H., and P. B. Tinker. 1977. Solute movement in the soil-root system. Blackwell Scientific, Oxford, UK.

Paige, K. N., and T. G. Whitham. 1987. Overcompensation in response to mammalian herbivory: the advantage of being eaten. American Naturalist 129:407-416.

Parrish, J. A. D., and F. A. Bazzaz. 1976. Underground niche separation in successional plants. 57:1281-1288.

Pearcy, R. W. 1999. Responses of plants to heterogeneous light environments. Pages 269-314 in F. I. Pugnaire and F. Valladares, editors. Handbook of functional ecology. Marcel Dekker, New York, New York, USA.

Pigliucci, M. 2001. Phenotypic plasticity: beyond nature and nurture (syntheses in ecology and evolution). Johns Hopkins University Press, Baltimore, Maryland, USA.

Poorter, H., and H. Lambers. 1986. Growth and competitive ability of a highly plastic and marginally plastic genotype of Plantago major in a fluctuating environment. Physiologia Plantarum 67:217-222.

Pregitzer, K. S., R. L. Hendrick, and R. Fogel. 1993. The demography of fine roots in response to patches of water and nitrogen. New Phytologist 125:575-580.

Redman, A. M., D. F. Cipollini, Jr., and J. C. Schultz. 2001. Fitness costs of jasmonic acid-induced defense in tomato, Lycopersicon esculentum. Oecologia 126:380-385.

Relyea, R. A. 2002. Costs of phenotypic plasticity. American Naturalist 159:272-282.

Reynolds, H. L., and C. D'Antonio. 1996. The ecological significance of plasticity in root weight ratio in response to nitrogen: opinion. Plant and Soil 185:75-97.

Rice, K. J., D. R. Gordon, J. L. Hardison, and J. M. Welker. 1993. Phenotypic variation in seedlings of a "keystone" tree species (Quercus douglasii): the interactive effects of acorn source and competitive environment. Oecologia 96: 537-547.

Richards, J. H. 1986. Root form and depth distribution in several biomes. Pages 83-97 in D. Carlisle, W. L. Berry, I. R. Kaplan, and J. R. Watterson, editors. Mineral exploration: biological systems and organic matter. PrenticeHall, Englewood Cliffs, New Jersey, USA.

Ridenour, W. M., and R. M. Callaway. 2001: The relative importance of allelopathy in interference: the effects of an invasive weed on a native bunchgrass. Oecologia 126:444450.

Robinson, D. 1994. Tansley Review Number 73. The responses of plants to non-uniform supplies of nutrients. New Phytologist 127:635-674.

Robinson, D., and I. H. Rorison. 1988. Plasticity in grass species in relation to nitrogen supply. Functional Ecology 2:249-257.

Ryser, P., and R. Notz. 1996. Competitive ability of three ecologically contrasting grass species at low nutrient supply in relation to their maximal relative growth rate and 
tissue density. Bulletin of Geobotanical Intitute ETH [Eidgenossische Techniche Zurich], 62:3-12.

Sagers, C. L., and P. D. Coley. 1995. Benefits and costs of defense in a neotropical shrub. Ecology 76:1835-1843.

Scharpf, R. F. 1975. Dwarf mistletoe-insect relationships. Pages 72-75 in Proceedings of the Joint Meeting, 26th Annual Western Forest Insect Work Conference and 22nd Annual Western International Forest Disease Work Conference (23-28 February, Monterey, California). USDA Forest Service, Intermountain Forest and Range Experiment Station, Ogden, Utah, USA.

Schenck, J., B. E. Mahall, and R. M. Callaway. 1999. Spatial segregation of roots. Advances in Ecology 28:145-180.

Schlichting, C. D. 1986. The evolution of phenotypic plasticity in plants. Annual Review of Ecology and Systematics 17:667-693.

Schlichting, C. D., and M. Pigliucci. 1998. Phenotypic evolution. A reaction norm perspective. Sinauer Associates, Sunderland, Massachusetts, USA.

Schmitt, J. 1993. Reaction norms of morphological and lifehistory traits to light availability in Impatiens capensis. Evolution 47:1654-1668.

Schmitt, J., S. A. Dudley, and M. Pigliucci. 1999. Manipulative approaches to testing adaptive plasticity: phytochrome mediated shade-avoidance responses in plants. American Naturalist 154:S43-S54.

Schmitt, J., A. C. McCormac, and H. Smith. 1995. A test of the adaptive plasticity hypothesis using transgenic and mutant plants disabled in phytochrome-mediated elongation responses to neighbors. American Naturalist 146:937-953.

Schreiner, O., and H. S. Reed. 1907. The production of deleterious excretions by roots. Bulletin of the Torrey Botanical Club 34:279-303.

Siemens, D. H., S. H. Garner, T. Mitchell-Olds, and R. M. Callaway. 2002. Cost of defense in the context of plant competition: Brassica rapa may grow and defend. Ecology 83:505-517.

Siemens, D. H., and T. Mitchell-Olds. 1998. Evolution of plant defense mechanisms: tests of theory on induced defenses. Ecology 79:632-646.

Silvertown, J., and D. M. Gordon. 1989. A framework for plant behavior. Annual Review of Ecology and Systematics 20:349-366.

Simms, E. L. 1992. Costs of plant resistance to herbivory. Pages $392-425$ in R. S. Fritz and E. L. Simms, editors. Plant resistance to herbivores and pathogens: ecology, evolution, and genetics. University of Chicago Press, Chicago, Illinois, USA.

Simms, E. L., and M. D. Rausher. 1987. Costs and benefits of plant resistance to herbivory. American Naturalist 130: 570-581.

Sorrensen-Cothern, K. A., E. D. Ford, and D. G. Sprugel. 1993. A model of competition incorporating plasticity through modular foliage and crown development. Ecological Monographs 63:277-304.

Stearns, S. C. 1989. The evolutionary significance of phenotypic plasticity. BioScience 39:436-445.

Steinger, T., and H. Müller-Schärer. 1992. Physiological and growth responses of Centaurea maculosa (Asteraceae) to root herbivory under varying levels of interspecific plant competition and soil nitrogen availability. Oecologia 91: 141-149.

Stenz, H. G., and M. H. Weisenseel. 1993. DC-electric fields affect the growth direction and statocyte polarity of root tips (Lepidum sativum). Journal of Plant Physiology 138: 335-344.

Stevens, R. E., and F. G. Hawksworth. 1970. Insects and mites associated with dwarf mistletoes. USDA Forest Service, Rocky Mountain Forest and Range Experiment Station, Fort Collins, Colorado, USA. Research Note RM-59.
Strauss-Debenedetti, S., and F. A. Bazzaz. 1996. Photosynthetic characteristics of tropical trees along successional gradients. Pages 162-186 in S. S. Mulkey, R. L. Chazdon, and A. P. Smith, editors. Tropical forest plant ecophysiology. Chapman and Hall, New York, New York, USA.

Strong, D. R., J. H. Lawton, and R. Southwood. 1984. Insects on plants. Community patterns and mechanisms. Harvard University Press, Cambridge, Massachusetts, USA.

Sultan, S. E. 1987. Evolutionary implications of phenotypic plasticity in plants. Evolutionary Biology 21:127-178.

Sultan, S. E. 1995. Phenotypic plasticity and plant adaptation. Acta Botanica Neerlandica 44:363-383.

Sultan, S. E. 2000. Phenotypic plasticity for plant development, function and life history. Trends in Plant Science 5: 537-542.

Sultan, S. E. 2001. Phenotypic plasticity for fitness components in Polygonum species of contrasting ecological breadth. Ecology 82:328-343.

Sultan, S. E., and F. A. Bazzaz. 1993a. Phenotypic plasticity in Polygonum persicaria. I. Diversity and uniformity in genotypic norms of reaction to light. Evolution 47:10091031.

Sultan, S. E., and F. A. Bazzaz. 1993b. Phenotypic plasticity in Polygonum persicaria. II. Norms of reaction to soil moisture and the maintenance of genetic diversity. Evolution 47:1032-1049.

Sultan, S. E., and F. A. Bazzaz. 1993c. Phenotypic plasticity in Polygonum persicaria. III. The evolution of ecological breadth for nutrient environment. Evolution 47:1050-1071.

Tang, C.-S., W.-F. Cai, K. Kohl, and R. K. Nishimoto. 1995. Plant stress and allelopathy. Pages $142-157$ in Inderjit, K. M. M. Dakshini, and F. A. Einhellig, editors. Allelopathy: organisms, processes, and applications. American Chemical Society, Washington, D.C., USA.

Tilman, D. 1988. Plant strategies and the dynamics and structure of plant communities. Princeton University Press, Princeton, New Jersey, USA.

Trumble, J. T., D. M. Kolodny-Hirsch, and I. P. Ting. 1993. Plant compensation for herbivory. Annual Review of Entomology 38:93-119.

Turkington, R. 1983. Plasticity in growth and patterns of dry matter distribution of two genotypes of Trifolium repens grown in different environments of neighbors. Canadian Journal of Botany 61:2186-2194.

Turkington, R. 1990. The influence of grass root systems on growth and form of Trifolium repens. Canadian Journal of Botany 68:1034-1038.

Turkington, R. 1991. Within-population variation in localized and integrated responses of Trifolium repens to biotically patchy environment. Oecologia 86:183-192.

Van Dam, N. M., and I. T. Baldwin. 1998. Costs of jasmonateinduced responses in plants competing for limited resources. Ecology Letters 1:30-33.

Van Kleunen, M., and M. Fischer. 2001. Adaptive evolution of plastic foraging responses in a clonal plant. Ecology 82: 3309-3319.

Van Tienderen, P. H. 1991. Evolution of generalists and specialists in spatially heterogeneous environments. Evolution 45:1317-1331.

Via, S. 1994. The evolution of phenotypic plasticity: what do we really know? Pages 35-57 in L. A. Real, editor. Ecological genetics. Princeton University Press, Princeton, New Jersey, USA.

Via, S., and R. Lande. 1985. Genotype-environment interaction and the evolution of phenotypic plasticity. Evolution 39:505-522.

Weinig, C. 2000a. Differing selection in alternative competitive environments: shade avoidance responses and germination timing. Evolution 54:124-136. 
Weinig, C. $2000 b$. Plasticity versus canalization: population differences in the timing of shade-avoidance responses. Evolution 54:441-451.

Weinig, C. $2000 c$. Limits to adaptive plasticity: temperature and photoperiod influence shade-avoidance responses. American Journal of Botany 87:1660-1668.

Weinig, C., and L. F. Delph. 2000. Phenotypic plasticity early in life constrains developmental responses later. Evolution 55:930-936.

Werner, E. E., and S. D. Peacor. 2003. A review of traitmediated indirect interactions in ecological communities. Ecology 84:1083-1100.

Wiersum, L. K. 1958. Density of root branching as affected by substrate and separate ions. Acta Botanica 7:174-179.

Wilson, S. D. 1991. Plasticity, morphology and distribution in twelve lakeshore plants. Oikos 62:292-298.
Wilson, S. D., and P. A. Keddy. 1986. Measuring diffuse competition along an environmental gradient: results from a shoreline plant community. American Naturalist 127: $862-869$.

Zangerl, A. R., A. M. Arntz, and M. R. Berenbaum. 1997. Physiological price of an induced chemical defense: photosynthesis, respiration, biosynthesis, and growth. Oecologia 109:433-441.

Zangerl, A. R., and F. A. Bazzaz. 1983. Responses of an early and a late successional specis of Polygonum to variations in resource ability. Oecologia 56:397-404.

Zangerl, A. R., and F. A. Bazzaz. 1992. Theory and pattern in plant defense allocation. Pages 363-391 in R. S. Fritz, and E. L. Simms, editors. Plant resistance to herbivores and pathogens: ecology, evolution, and genetics. University of Chicago Press, Chicago, Illinois, USA. 